\title{
Effects of Steam Dosage on the Qualities of Activated Carbon Developed From Coconut Shells in Ghana
}

\author{
Essuah, E.Y., Buah, W. K.* \\ University of Mines and Technology, P. O. Box 237, Tarkwa
}

*Corresponding Author: Buah, W. K., University of Mines and Technology, P. O. Box 237, Tarkwa

\begin{abstract}
Physical methods of activated carbon production, investigating activation at different temperatures and times, have been studied extensively by some researchers. However, much work has not been presented on the effects of steam dosage on activated carbon production. This paper presents the effects of steam dosage on the qualities of activated carbons produced from coconut shells. Coconut shells were crushed, carbonized at a temperature of $900^{\circ} \mathrm{C}$ and subsequently activated at the same temperature for 3 hours using steam as the activating agent at different steam dosing rates. The results of the activation burnoff revealed that increase in steam dosage from $0.015 \mathrm{ml} / \mathrm{g} / \mathrm{min}$ increased the activation burn-off until 0.046 $\mathrm{ml} / \mathrm{g} / \mathrm{min}$ steam dosage which recorded the highest burn-off value and there after decreased toward 0.115 $\mathrm{ml} / \mathrm{g} / \mathrm{min}$ steam dosage. The iodine numbers of the activated carbons derived at $0.031,0.046$ and 0.062 $\mathrm{ml} / \mathrm{g} / \mathrm{min}$ steam dosing rates were higher than that of a commercially developed activated carbon (PJACPJ612 CO650 LAI), investigated in this research. The gold adsorption performance of the activated carbons derived at 0.015, 0.031, 0.046, 0.062 and $0.077 \mathrm{ml} / \mathrm{g} / \mathrm{min}$ were also higher than that of the commercially produced activated carbon.
\end{abstract}

Keywords: surface area, burn-off, porosity, carbonization and activation.

\section{INTRODUCTION}

Carbonaceous materials with larger surface area, higher degree of surface reactivity and demonstrate a higher capacity for adsorbing a lot of substances due to enormous number of pores on their surface are termed as activated carbon (Dias et al., 2007). They are made from lignocellulose materials (Tay et al., 2001; Finqueneisel et al., 1998) and coal (Srinvasakannan and Abu-Bakar, 2006). Agricultural wastes such as coconut shells (Bentil and Buah 2017), palm kernel shells (Vitidsant et al., 1999) and corn cobs (Buah et al., 2016) are few examples of lignocellulose materials that are used as precursors for the production of activated carbons.

Activated carbons are widely used as adsorbents in metal extraction industries as well as gas and liquid phase industries. Another most important field in terms of activated carbon consumption is portable and waste water treatment especially for heavy metals removal due to their negative ill effects on human beings (Salehzadeh, 2013; Mohammad et al., 2010).

Activated Carbons are conventionally prepared either by physical or chemical activation methods or both. In either method, a two stage process is employed in their production which involves an initial enrichment of carbon content to produce a carbonaceous mass full of tiny pores (Bentil and Buah, 2017), followed by either physical or chemical activation. In the physical activation process, the resultant char is activated by selectively oxidizing in presence of suitable gasifying agents like steam or $\mathrm{CO}_{2}$ at temperatures ranging from $600^{\circ} \mathrm{C}$ to $900^{\circ} \mathrm{C}$ (Park and Kim., 2001; Sanchez et al., 2001). Agents like phosphoric acid, zinc chloride or sulphuric acid (Kilic et al., 2012) are also used to chemically activate char at a temperature below $700^{\circ} \mathrm{C}$.

Commercial activated carbons are mostly produced from various grades of coal (Vijayan et al., 2012). The higher cost and lower availability of coal have encouraged many researchers to find alternate precursors which are cost effective and has equal potentials as coal.

Among the numerous agricultural wastes, coconut shells were selected for this research due to their availability with little or no value in rural areas in Ghana. It was estimated that $170.64 \times 103$ tons of this waste was generated in the year 2008 in Ghana and was projected to increase in the subsequent 
years (Quartey and Chylkova, 2013). Also, proximate and ultimate analysis conducted by Bentil and Buah (2017), Punsuwan et al. (2015), Iqbaldin et al. (2013) and Vitidsant et al. (1999) indicated that coconut shells have high fixed carbon content with relatively low amount of ash, more amount of volatile matter and are environmentally harmless due to their lower nitrogen and sulphur contents. Hence, waste coconut shells can be converted into activated carbons for industrial applications.

Recent works have emphasized on physical methods of production of activated carbons using steam as the activating agent by activating at different temperatures and times (Asadullah et al., 2007; Vitidsant et al., 1999). However, not much work has been done on investigating the effects of steam dosage on the development of activated carbons. In view of this; this research produced activated carbons from waste coconut shells using steam as the activating agent by optimizing activation steam dosing rate.

\section{MATERIALS AND MethodS}

\subsection{Materials}

Waste coconuts shells were obtained from Nzema-Kikam, in the Western Region of Ghana. Roll crusher was used to crush the coconut shells. A gas fired pyrolysis-gasification reactor was used for the carbonization and the activation process while the temperature of the reactor was measured using a k-type thermocouple. Iodine, sodium thiosulphate and starch were used to carry out iodine adsorption test to give an estimation of the surface area of the produced carbons. Ball pan, steel balls and a set of screens were used to perform the abrasion test. Again a $250 \mathrm{ml}$ measuring cylinder and furnace were used to carry out the apparent bulk density and the ash content of the carbons respectively.

\subsection{Preparation of Activated Carbons}

The coconut shells were crushed and sieved to obtain a fraction having particle sizes of 1.7-2.8 mm. The sized fraction of the shells were loaded into in a gas fired pyrolysis-gasification reactor to produce activated carbons according to the procedures detailed in Figure 1. The first step in the activation process was carbonization of the shells to enrich the carbon content to produce a carbonaceous mass full of tiny pores called the char by driving out the volatiles and all traces of chemically combined water from the shell at a temperature of $900^{\circ} \mathrm{C}$. The next step was activation of the derived char at a temperature of $900^{\circ} \mathrm{C}$ for 3 hours but at a various steam dosages. The entire activation process was repeated to ascertain the repeatability of the results.

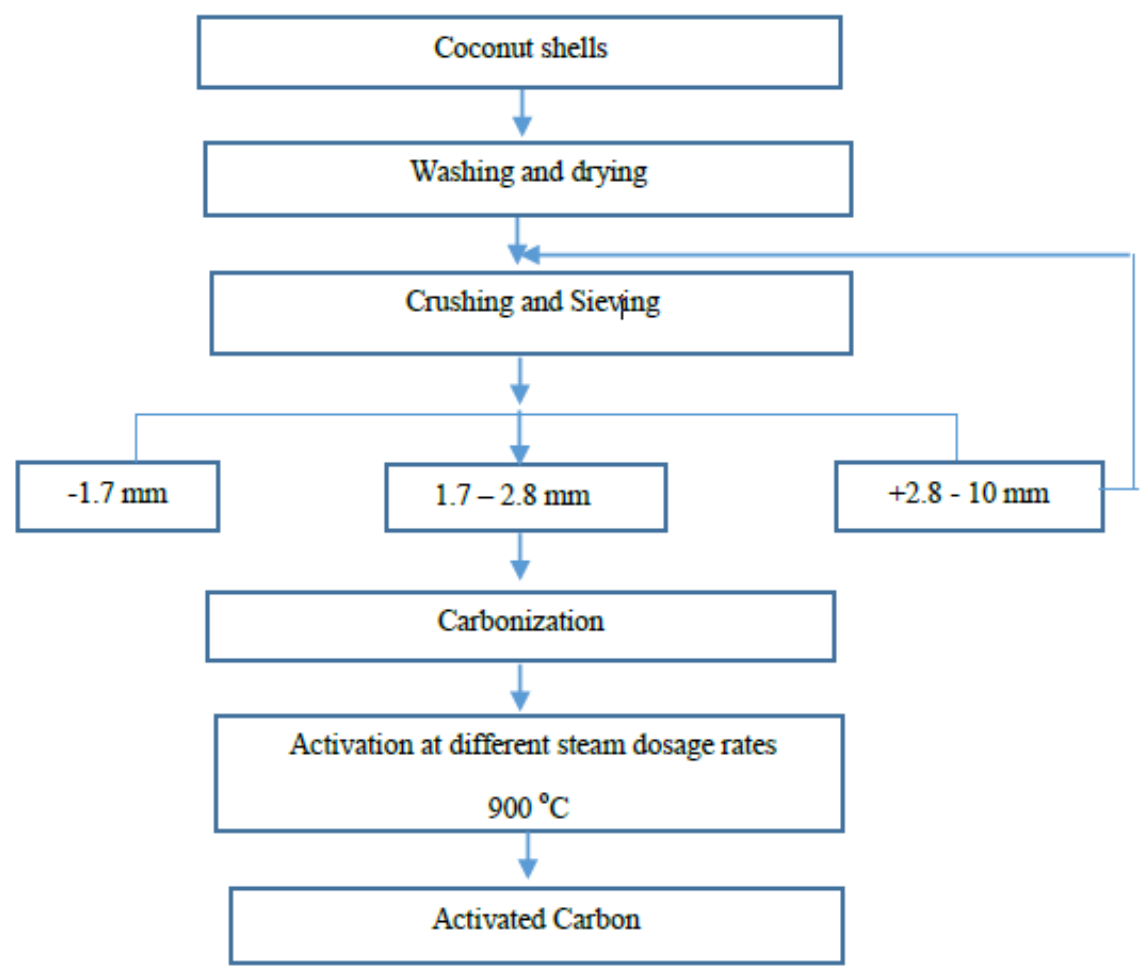

Figure1. Framework of the Procedure for Preparing the Coconut Based Activated Carbon 


\subsection{Carbon Analysis}

Burn-off, ash content, apparent bulk density, hardness and iodine number were determined for the derived carbons. There was a significant relationship among them and for their application in metal adsorption. Commercial carbon (PJAC- PJ612 CO650 LAI) was used as a reference in order to judge some characteristics of the produced activated carbons.

\section{RESUlTS AND DISCUSSIONS}

\subsection{Activation Burn-Off, Percent Production Yield and Total Ash Content}

The percent activation yield, total ash content and the burn-off were found to be greatly varied with varying activation steam dosing rate. Figure 2 shows the effect of steam dosage on the production yield, ash content and percent activation burn-off of the activated carbons produced at a temperature of $900^{\circ} \mathrm{C}$ for 3 hours activation.

The activation burn-off and the percent ash plots in Figure 2 show that both the percent burn-off and the ash content increased as the steam dosing rate was increased until at a flow rate of $0.046 \mathrm{ml} / \mathrm{g} / \mathrm{min}$, which recorded the highest burn-off and ash content, then they decreased towards the flow rate of $0.115 \mathrm{ml} / \mathrm{g} / \mathrm{min}$. On the other hand, an increase in steam dosing rate reduced the percent yield until $0.046 \mathrm{ml} / \mathrm{g} / \mathrm{min}$ steam dosing rate then increased toward $0.115 \mathrm{ml} / \mathrm{g} / \mathrm{min}$ steam flow rate.

The increase in activation burn-off until $0.046 \mathrm{ml} / \mathrm{g} / \mathrm{min}$ steam rate could be because; the carbon reacted with the generated steam at a faster rate due to the greater availability of steam in the reactor. This effect resulted in the volatilization of more amount of volatile substances from the carbon pores and further developed the pores to create a higher internal surface area (Lee et al., 2014; Asadullah et al., 2007; Tan et al., 2007; Bae et al., 2014). Again, there was a partial oxidation of some carbon particles in the reactor as the steam dosage increased to $0.046 \mathrm{ml} / \mathrm{g} / \mathrm{min}$ but to a lesser extent. Some carbon particles on the surface of the reactor were converted into ash whiles pore development was high on carbon particles that stayed deeply at the same time.

However, the decrease in the percentage burn-off after $0.046 \mathrm{ml} / \mathrm{g} / \mathrm{min}$ of steam dosage which caused high production yield could be attributed to the reduction in effective activation temperature due to excessive water flow rate above the quantity required for effective steam generation. Hence heat was being consumed in vaporizing excess water rather than vaporizing and activating the carbons simultaneously.

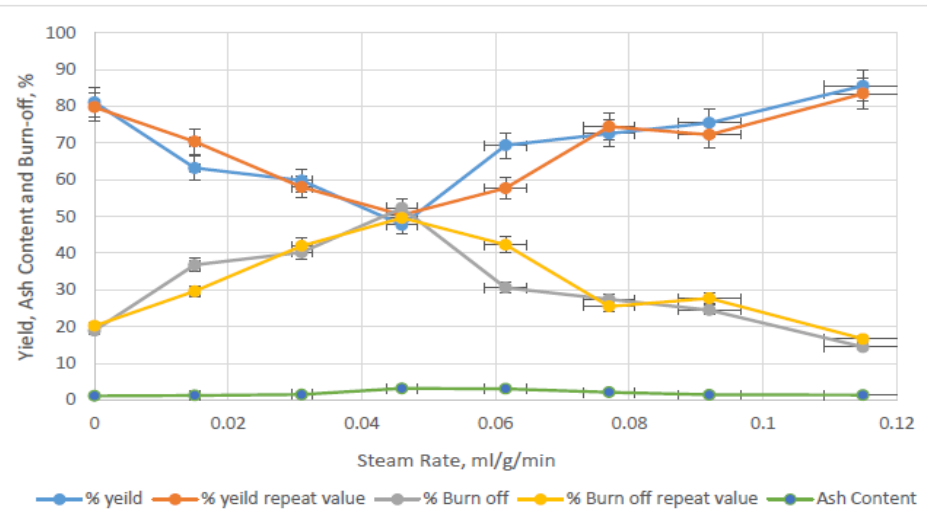

Figure2. Effect of Steam Dosing Rate on Ash Content, Percent Activation Burn-off and Percent Production Yield of the Coconut Shell Based Activated Carbons Derived at $900^{\circ} \mathrm{C}$ and 3 Hours of Activation.

\subsection{Iodine Adsorption Number}

The iodine number indicates the porosity of the activated carbon and it is defined as the milligram of iodine adsorbed by $1 \mathrm{~g}$ of carbon (Anon, 1986). The iodine number is a technique used to determine the adsorption capacity of carbons and sometimes maybe used to approximate surface area and microporosity with good precision (Jianzhong et al., 2014; Park and Kim, 2001).

The iodine number values of the derived carbons were measured as $238.580 \mathrm{mg} / \mathrm{g}$ and $248.733 \mathrm{mg} / \mathrm{g}$ for the carbons derived at $0.031 \mathrm{ml} / \mathrm{g} / \mathrm{min}$ and $0.046 \mathrm{ml} / \mathrm{g} / \mathrm{min}$ of steam dosage respectively. Thereafter, the iodine number value gradually dropped to a value of $30.457 \mathrm{mg} / \mathrm{g}$ at $0.115 \mathrm{ml} / \mathrm{g} / \mathrm{min}$ steam dosage. The decrease in iodine adsorption number value of the carbons derived after 0.046 $\mathrm{ml} / \mathrm{g} / \mathrm{min}$ was considered to be as a result of the decrease in the activation burn-off caused by 
excessive consumption of heat in vaporizing excess water rather than vaporizing and activating the carbons simultaneously. As a result, there was a reduction in effective activation temperature. This trend indicates that carbon derived at $0.046 \mathrm{ml} / \mathrm{g} / \mathrm{min}$ is optimum in our study.

In view of this result, it appears that carbon derived at $0.046 \mathrm{ml} / \mathrm{g} / \mathrm{min}$ will possess the highest surface area since literature survey indicates that the value of iodine number correlates highly with BrunauerEmmett-Teller (BET) surface area (Vitidsant et al., 1999; Meteku, 2014; Jianzhong et al., 2014). The iodine adsorption number of the derived activated carbons and that of the commercially produced carbon are shown in Figure 3.

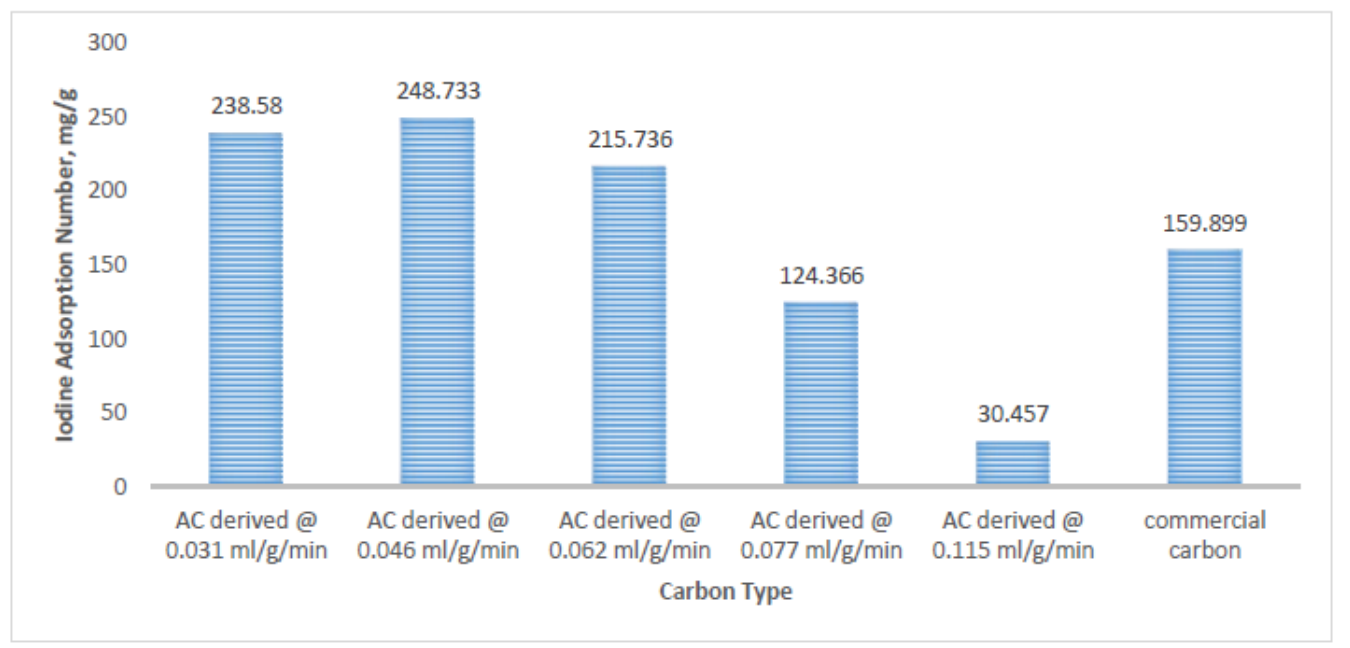

Figure3. Iodine Adsorption Number of the Derived Carbons and that of the Commercially Produced Carbon

\subsection{Hardness (The Ball Pan Hardness)}

One important criteria in the selection of activated carbon for industrial application is the hardness of the carbon especially in the carbon-in-leach or carbon-in-pulp applications where agitation may lead to high attrition. The hardness of activated carbon is its ability to resist breakdown or attrition when in use. It is an important indicator of the carbon to maintain its physical integrity and withstand frictional forces. Low attrition carbons have high tendency to produce too many fines or dust which makes its applications in the aqueous media unfriendly. In the gold processing industries for instance, fine carbons with high gold loadings generated during adsorption and transfer processes in the tanks could escape inter tank screens. This effect may cause gold being lost on undersized carbon particles to tails in gold plant operations. As a result, activated carbon for aqueous phase applications should possess reasonable mechanical strength to withstand high abrasion during its usage. The ball pan hardness of the activated carbons derived at varied steam dosing rates for 3 hours of activation at $900^{\circ} \mathrm{C}$ were recorded and presented in Figure 4.

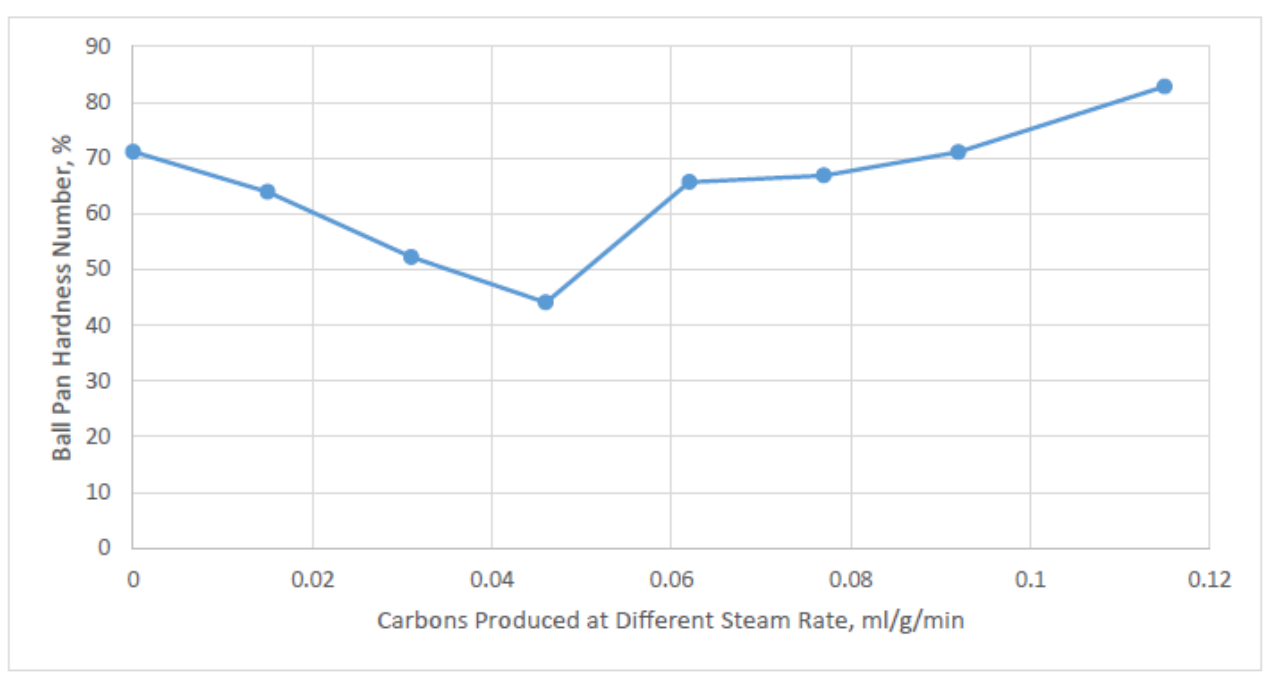

Figure4. Effect of Steam Dosing Rate on Ball Pan Hardness of the Coconut Shell Based Activated Carbons Derived at $900^{\circ} \mathrm{C}$ and 3 Hours of Activation. 
It is observed from Figure 4 that activation steam rate had an impact on the hardness of the derived activated carbons. There was a decrease in hardness with increase in steam dosing rate until carbon derived at $0.046 \mathrm{ml} / \mathrm{g} / \mathrm{min}$. Further increase in the steam flow rate resulted in increase in the hardness of the derived carbons.

The decrease in carbon hardness may be attributed to the action of the steam which apart from serving as oxidizing agent also caused high activation burn-offs and removed tar entrapped in between the pores of the carbon during the activation. It could be explained that, carbon burn-off is a function of hardness and that increase in activation burn-off will render the carbon fragile (Asadullah et al., 2007; Bentil, 2017).

However, the rise in percent hardness of the carbons derived after $0.046 \mathrm{ml} / \mathrm{g} / \mathrm{min}$ could be attributed to the reduction in effective activation temperature within the activation chamber due to excessive water flow rate beyond the required threshold for effective steam generation. The reduction in the effective activation temperature caused lower burn-offs resulting in the removal of relatively little tar entrapped between the carbon pores hence rendering the carbons much stronger.

\subsection{Apparent Bulk Density}

Bulk density is an important parameter of divided solids especially for fine and granular activated carbons. It is defined as mass per unit volume of a material (activated carbons) including voids in the material. A low bulk density carbon sometime may imply relatively high surface area, hence a good indicator of high adsorption capacity (Saleh et al., 2008).

The solid or skeletal density of activated carbon typically range between $2.0 \mathrm{~g} / \mathrm{cm}^{3}$ and $2.1 \mathrm{~g} / \mathrm{cm}^{3}$. However due to the air space between particles, the volume or the apparent bulk density will be far lower compared to the solid density of the carbon. As a result, the American Water Work Association (AWWA) has set a lower limit of $0.25 \mathrm{~g} / \mathrm{cm}^{3}$ as the standard density for activated carbon for practical use (Anon, 1991). The apparent bulk densities of the various activated carbons produced from the coconut shells by varying steam dosing rate, keeping a temperature of $900^{\circ} \mathrm{C}$ and for 3 hours activation time are presented in Figure 5.

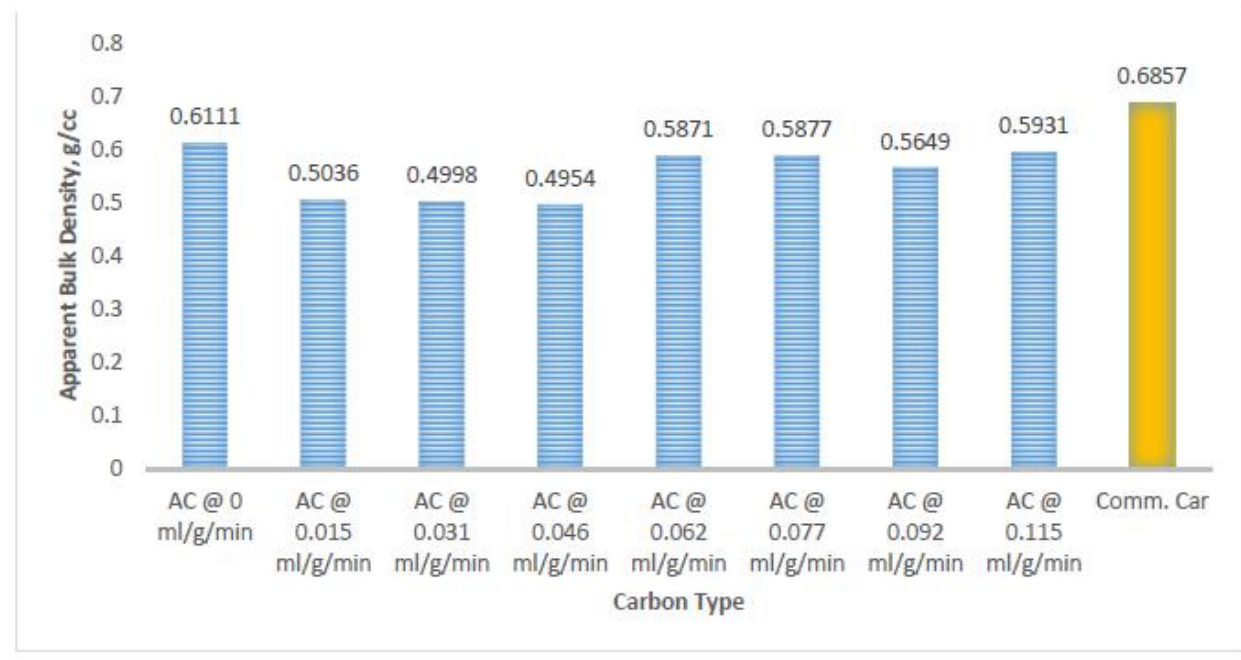

Figure5. Effect of Activation Steam Rate on the Apparent Bulk Density of the Coconut Shell Based Activated Carbons Derived at $900^{\circ} \mathrm{C}$ and 3 Hours of Activation in Relation to that of the Commercial Carbon.

From Figure 5, it is observed that carbons produced at $0 \mathrm{ml} / \mathrm{g} / \mathrm{min}$ steam rate recorded a higher bulk density of $0.61 \mathrm{~g} / \mathrm{cm}^{3}$. This implies that at $0 \mathrm{ml} / \mathrm{g} / \mathrm{min}$ flow rate there was a relatively little removal of volatile matter from the carbon which resulted in higher bulk density.

The bulk density of the carbons reduced at an initial steam rate of $0.015 \mathrm{ml} / \mathrm{g} / \mathrm{min}$ until at a steam rate of $0.046 \mathrm{ml} / \mathrm{g} / \mathrm{min}$, which recorded the least bulk density value of $0.4954 \mathrm{~g} / \mathrm{cm}^{3}$. The bulk density decreased from an initial steam rate of $0.015 \mathrm{ml} / \mathrm{g} / \mathrm{min}$ to $0.046 \mathrm{ml} / \mathrm{g} / \mathrm{min}$ because the steam penetrated into the surface of the carbon particles, so it meant that the effective steam generated in the reactor evaporated more volatile compounds in the inner part of the carbon particles. As a result, porosity was developed on the derived carbons (Vitidsant et al., 1999) and the weight of the activated carbon per the total volume occupied by the carbons decreased. 
However, the bulk densities increased for carbons produced at steam dosage of $0.062 \mathrm{ml} / \mathrm{g} / \mathrm{min}$ until at a steam rate of $0.092 \mathrm{ml} / \mathrm{g} / \mathrm{min}$, which reduced slightly from $0.5877 \mathrm{~g} / \mathrm{cm}^{3}$ at a steam rate of 0.077 $\mathrm{ml} / \mathrm{g} / \mathrm{min}$ to $0.5649 \mathrm{~g} / \mathrm{cm}^{3}$ and increased again to a bulk density value of $0.5931 \mathrm{~g} / \mathrm{cm}^{3}$ at steam rate of $0.115 \mathrm{ml} / \mathrm{g} / \mathrm{min}$. The general increase in bulk density with increase in steam dosage from 0.062 $\mathrm{ml} / \mathrm{g} / \mathrm{min}$ could be as a result of reduced burn-off due the reduction in effective activation temperature caused by the excessive water flow rate beyond the needed amount for effective vaporization.

In comparison to the commercial carbons, all the derived activated carbons have lower bulk density values than the commercially produced activated carbons. Also the bulk density values obtained per this study indicate that all the densities of the derived carbons ranged from 0.4954 to $0.6111 \mathrm{~g} / \mathrm{cm}^{3}$ which were all far above the minimum set value of $0.25 \mathrm{~g} / \mathrm{cm}^{3}$ for practical use according to the AWWA standard (Anon, 1991).

\subsection{Gold Adsorption Performance}

In gold plant operations, gold loss can be associated with adsorption rate and one of the most important requirements of activated carbons used for gold adsorption in the gold extraction industry is its ability to possess a higher gold adsorption rate. Thus, rapid adsorption rate will minimize gold loss even at low concentrations of carbon in the adsorption process, which in turn can lead to high gold loading on the carbons (Arol and Yalcin, 2002).

All the eight (8) different carbon types prepared under different steam rate together with the commercial activated carbons were subjected to gold adsorption rate test. The rate of gold adsorption of the individual activated carbon types were measured by their R-values. Table 1 shows the deduced $\mathrm{R}$-values which is the reciprocal of the intercept after plotting a graph of time divided by the gold loadings on the carbons versus time.

The R-value for each carbon is relative, i.e. a higher value indicates faster adsorption rate. Higher Rvalue possessed by the carbons may be due to their larger pore volume, larger surface area and surface functional groups present on the carbon surface. Per the R-value data shown in Table 1 the gold adsorption rate was appreciably better with carbons produced at steam rate of $0.015,0.031,0.046$, 0.062 and $0.077 \mathrm{ml} / \mathrm{g} / \mathrm{min}$ compared to the commercial activated carbon. Even though carbons derived at steam rate of $0.031 \mathrm{ml} / \mathrm{g} / \mathrm{min}$ recorded the second highest iodine number value (surface area), its highest gold adsorption rate may be attributed to the possibility of the carbons possessing suitable surface functional groups which enabled their faster gold adsorption rate than the remaining carbon types.

Table1. $R$-Values of the Derived Carbons.

\begin{tabular}{|c|c|c|}
\hline $\begin{array}{c}\text { Activated Carbon Produced at Various } \\
\text { Steam Dosing Rate, } \mathbf{~ m l} / \mathbf{g} / \mathbf{m i n}\end{array}$ & $\begin{array}{c}\text { "R- Value, } \mathbf{~ m g} \\
\mathbf{A u} / \mathbf{h} / \mathbf{g}\end{array}$ & $\begin{array}{c}\text { Percent Gold Adsorbed after 1 hr, } \\
\text { \% }\end{array}$ \\
\hline Carbon produced at 0 & 0.04186 & 32.50 \\
\hline Carbon produced at 0.015 & 0.62980 & 97.11 \\
\hline Carbon produced at 0.031 & 1.06929 & 98.39 \\
\hline Carbon produced at 0.046 & 0.71927 & 97.63 \\
\hline Carbon produced at 0.062 & 0.43579 & 96.93 \\
\hline Carbon produced at 0.077 & 0.09187 & 92.58 \\
\hline Carbon produced at 0.092 & 0.08004 & 64.14 \\
\hline Carbon produced at 0.115 & 0.04488 & 21.52 \\
\hline Commercial Carbon & 0.18945 & 88.91 \\
\hline
\end{tabular}

\section{CONCLuSiOnS}

This study established the effects of steam dosage on the qualities of activated carbons produced from coconut shells in Ghana using steam as the activating agent. It was established that the activation burn-off was a function of steam dosage since an increase in the steam dosage from $0.015 \mathrm{ml} / \mathrm{g} / \mathrm{min}$ increased the activation burn-off until $0.046 \mathrm{ml} / \mathrm{g} / \mathrm{min}$ steam rate which recorded the highest burn-off value and there after the percent burn-off decreased towards $0.115 \mathrm{ml} / \mathrm{g} / \mathrm{min}$ of steam dosage. It was also established that an increase in percent burn-off caused an increase in the iodine number value of the produced carbons, decreased the bulk density and also rendered the carbons fragile. Even though the carbons derived at the steam rate of $0.046 \mathrm{ml} / \mathrm{g} / \mathrm{min}$ recorded the least hardness value after the ball pan hardness test, the carbons however seemed to be reasonably hard and showed no breakages 
during the gold adsorption. Also the carbons derived at 0.015, 0.031, 0.046, 0.062 and $0.077 \mathrm{ml} / \mathrm{g} / \mathrm{min}$ demonstrated a very high gold adsorption rate than the commercial activated carbons investigated in this research. This research has demonstrated the feasibility of producing activated carbons from coconut shells in Ghana for gold adsorption application.

\section{REFERENCES}

[1] Anon. (1986), "Standard Test Method for Iodine Number in Activated Carbon", American Standard for Testing of Materials, ASTM D 4607-862.

[2] Anon. (1991), "America Water Works Association, AWWA Standards for Granular Activated Carbons, America Water Works Association/ArvSI/AWWA B604- 90 Denver Co.

[3] Anon. (2005), "Standard Test Method for Ball-Pan Hardness of Activated Carbon", American Standard for Testing of Materials, ASTM D 3802-79.

[4] Arol, A. I. and Yalcin, M. (2002), "Gold Cyanide Adsorption Characterization of Activated Carbon of Non- coconut Shell Origin" Carbon, Vol. 63, pp. 201-206.

[5] Asadullah, M., Rahman, M. A., Motin, M. A. and Sultan, M. B. (2007), "Adsorption Studies on Activated Carbon Derived from Steam Activation of Jute Stick Char", Journal of Surface Technology, Vol. 23, No. 1-2, pp. 73-80.

[6] Bae, W., Kim, J. and Chung, J. (2014), "Production of Granular Activated Carbon from Food- processing Wastes (Walnut Shells and Jujube Seeds) and Its Adsorptive Properties", Journal of Air and Waste Management Association, Vol. 64, pp. 879-886.

[7] Bentil, J. (2017), "Preparation of Physically Activated Carbons from Selected Agro-solid Wastes and their Applications", Unpublished Ph.D. Thesis Report, University of Mines and Technology, Tarkwa, Ghana, pp. 105-109.

[8] Bentil, J. and Buah, W. K. (2017), "Effects of Physical Activation Procedure on the Production Yield, Surface Chemistry and Surface Pores of Coconut Shells Based Activated Carbons", Chemistry and Material Research, Vol.9, No.3, pp. 29-35.

[9] Buah, W. K., MacCarthy, J. and Ndur, S. (2016), "Conversion of Corn Cobs Waste into Activated Carbons for Adsorption of Heavy Metals from Minerals Processing Wastewater", International Journal of Environmental Protection and Policy, Vol. 4, No. 4, pp. 98 - 103

[10] Dias, J. M., Alvim-Ferraz, M. M., Almeida, M. F., Rivera-Utrilla, J., and Sanchez-Polo, M. (2007), "Waste Materials for Activated Carbon Preparation and its Use in Aqueous -Phase Treatment", A review. Journal of Environmental Management, pp. 833-846.

[11] Finqueneisel, G., Zimny, T., Vogt, D., Weber, J.V. (1998), "Feasibility of the Preparation of Effective Cheap Adsorbent from Lignites in Rotary Kiln", Fuel Technology, Vol. 57, pp. 195-208.

[12] Iqbaldin, M. N. M., Khudzir, I., Azlan, M. I. M., Zaidi, A. G., Surani, B. and Zubri, Z. (2013), "Properties of Coconut Shell Activated Carbon", Journal of Tropical Forest Science, Vol. 25, No. 4, pp. 497-503.

[13] Jianzhong, X., Lingzhi, C. and Xiaojie, F. (2014), "Preparation and Characterization of Activated Carbon from Reedy Grass Leaves in a Two-step Activation Procedure", International Conference on Material and Environmental Engineering, ICMAEE 2014, pp. 1-12.

[14] Kilic, M., Apaydin-Varol, E. and Putun, A. E. (2012). "Preparation and Surface Characterization of Activated Carbon from Euphorbia Rigida by Chemical Activation with $\mathrm{ZnCl} 2, \mathrm{~K} 2 \mathrm{CO} 3, \mathrm{NaOH}$ and H3PO4", Applied Science, Vol. 261, pp. 247-254.

[15] Lee, K. T., Nor, N. M., Lau. L. C. and Mohamed, A. R., (2013), "Synthesis of Activated Carbon from Lignocellulosic Biomass and its Applications in Air Pollution Control", A Review. Journal of Environmental Chemical Engineering, Vol. 1, No. 4, pp. 658-666

[16] Meteku, B. E. (2014), "Evaluation of the Correlation between Selected Quality Indices of Activated Carbon- A Review", Asian Journal of Applied Science and Engineering, Vol. 3, pp. 42-50.

[17] Mohammed, A. R., Mohammad, M. and Darzi, G. N. (2010), "Preparation of Carbon Molecular Size from Lignocellulosic Biomass", A Renewable and Sustainable, Energy Reviews, Vol. 14, No. 6, pp.169-181.

[18] Park, S. J. and Kim, Y. M. (2001), "Adsorption Behaviour of Heavy Metal Ions onto Electrochemically Oxidizes Activated Carbon Fibers”, Mat. Sci. Eng. A-Struct., Vol. 391, pp. 121-123.

[19] Punsuwan, M., Tangsathitkulchai, C. and Takarada, T. (2015). "Low Temperature Gasification of Coconut Shell with $\mathrm{CO} 2$ and $\mathrm{KOH}$ : Effects of Temperature, Chemical Loading and Introduced Carbonisation Step on the Properties of Syngas and Porous Carbon Product", International Journal of Chem. Eng., Vol. 2015, pp. 1- 16.

[20] Quartey, E. T. and Chylkova, J. (2013), "Challenges and Opportunities in Managing Agricultural Waste in Ghana", Advances in Environment, Biotechnology and Biomedicine, pp. 235-239. 
[21] Saleh, N.J., Ismaeel, M.I., Ibrahim, R.I., Zablouk, M.A. and Amer, A. (2008), "Preparation of Activated Carbon from Iraqi Reed", Engineering \& Technology Journal, Vol. 26, No. 3, pp. 291-304.

[22] Salehzadeh, J. (2013), "Removal of Heavy Metals Pb2+, Cu2+, Zn2+, Cd2+, Ni2+, Co2+, and Fe3+ from Aqueous Solution by Xanthium Pensylvanicum”, Leonardo Journal of Science, Vol. 23, pp 97-104.

[23] Sanchez, A. R., Elguezabel, A. A. and Saenz, L. L. T. (2001), "CO2 Activation of Char from Quercus Agrifolia Wood Waste”, Carbon, Vol. 39, No. 9, pp. 1367-1377.

[24] Srinivasakannan, C. and Abu-Bakar, M. Z. A. (2006), "Production of Activated Carbon from Rubber Wood Sawdust", Biomass and Bioenergy, Vol.27, pp. 89-96.

[25] Tay, J.H., Chen, X.G., Jeyaseelan, S. and Graham, N. (2001), "Optimising the Preparation of Activated Carbon from Digested Sewage Sludge and Coconut Husk", Chemosphere, Vol. 44, pp 45-51.

[26] Tan, I. A. W., Hameed, B. H. and Ahmad, A. L. (2007), "Equillibrium and Kinetics Studies on Basic Dye Adsorption by Oil Plam Fibre Activated Carbon”, Chemical Engineering Journal, Vol. 127, pp. 111-119.

[27] Vitidsant, T., Suravattanasakul, T. and Damronglerd, S., (1999), "Production of Activated Carbon from Palm Oil Shell by Pyrolysis and Steam Activation in a Fixed Bed Reactor”, ScienceAsia, Vol. 25, pp. 211222.

[28] Vijayan, S. N., Makeshkumar, M. and Sridhar, K., (2012), "Physical and Chemical Analysis of Activated Carbon Prepared from Coconut Shell Charcoal and Usage- A Case Study", International Journal of Advanced Scientific Research and Technology, Vol.3, pp. 168-175.

Citation: Essuah, E.Y., Buah, W. K., (2019)" Effects of Steam Dosage on the Qualities of Activated Carbon Developed From Coconut Shells in Ghana", Southeast Cameroon, International Journal of Mining Science (IJMS), 5(4), pp.22-29, DOI: http://dx.doi.org/10.20431/2454-9460.0504002

Copyright: () 2019 Authors. This is an open-access article distributed under the terms of the Creative Commons Attribution License, which permits unrestricted use, distribution, and reproduction in any medium, provided the original author and source are credited 